\title{
Intraneural Perineurioma
}

National Cancer Institute

\section{Source}

National Cancer Institute. Intraneural Perineurioma. NCI Thesaurus. Code C6911.

A WHO grade I perineurioma that arises within the endoneurium. It is characterized by the formation of pseudo-onion bulbs by the proliferating perineural cells. 